\title{
STUDI ARKEOMETALURGI DALAM DISIPLIN ARKEOLOGI
}

\author{
Oleh: Timbul Haryono
}

\section{Pengantar}

Perkembangan ilmu arkeologi dewasa ini terasa begitu cepat. Sasaran atau jangkauan ilmu ini telah lebih luas ialah segala aspek yang berhubungan dengan kehidupan manusia masa lalu. Para ahli arkeologi didorong oleh suatu motivasi yang tidak hanya ingin mengetahui nilai-nilai keindahan benda-benda yang mereka temukan akan tetapi lebih dari itu ialah ingin mendapatkan keterangan-kelerangan yang lebih banyak yang dapat diungkap dari hasil temuan mereka tentang masa lampau.

Perkembangan tersebut sedikit banyak telah mengubah perspektif dalam diri seorang ahli. Seperti misalnya Paul S. Martin yang menyadari ak an adanya kecenderungan ke arah kerangka kerja baru dalam arkeologi:

"We archaeologist, too, were confronted with the bewildering and perplexing fact of a disparity between what we wanted to accomplish an explanation of why cultures change - and what we were actually doing - histories of sites" (Martin, 1971: 1-8).

Memang banyak pandangan-pandangan tentang jangkauan ilmu arkeologi, dan nampaknya ada titik pertemuan terhadap sasaran pokok arkeologi (Binford, 1968: 8-16):

1. Rékonstruksi sejarah kebudayaan

2. Rekonstruksi cara hidup manusia masa lamipau

3. Siudi proses kebudayaan.

Di dalam usaha merekonstruksi kehidupan masa lampau, tugas kita bukan semata-mata menguraikan serangkaian peristiwa yang abstrak dan terlepas lepas. Masa lampau yang akan kita susun kembali terdiri dari kehidupan perorangan yang tergabung dan membentuk suatu peristiwa.

Kehidupan masa lampau sangat kompleks; untuk menyususnnya kembali kita hanya punya data arkeologi yang kurang lengkap sebab data tersebut sampai ke tangan kita sudah mengalami proses pemindahan yang bermacam-macam. Proses pemindahan kebudayaan ini kemudian melahirkan studi 'taphonomy'. (Gifford 1981).

Jangkauan ilmu arkeologi seperti telah disebut telah menyebabkan ilmu arkeologi dalam perkembangannya memerlukan kerja sama dengan ilmu lain. Salah satu yang menjadi pokok pembıcaraan dalam makalah ini adalah metalurgi. 


\section{Metalurgi dan Metalografi}

\section{Metalurgi}

Metalurgi dalam pengertian ini ialah suatu teknologi yang kompleks yang mencakup dua sasaran pokok, yaitu:

a. Cara pengambilan logam dari bijihnya

b. Cara membuat ar tefak dari logam.

Berdasarkan hal tersebut, maka secara teknis metalurgi dapat didefinisikan sebagai ilmu yang mempelajari cara-cara esktrasi metal dari sumbernya (menambang) dan teknik pembuatan alat-alat metal (Grosvenor, 1954: 1).

Metalurgi pada awal perkembangannya masih lebih merupakan suatu 'art' dari pada sebagai 'science', Namun dalam perkembangannya kemudian, metalurgi menjadi 'science' yang berhubungan erat dengan kimia. Kalau di dalam pembicaraan ini digunakan istilah 'arkeometalurgi' maka sasarannya menjadi lebih jelas ialah studi metalurgi masa lampau berdasarkan peninggalan arkeologi yang berkaitan erat dengan logam (metal).

Fase historis arkeometalurgi mencakup beberapa tahap. Berdasarkan bukti arkeologis yang ditemukan di Irak, Iran, dan Mesopotamia, proses perkembangannya terdiri atas (Wertime 1973):

1. Penggunaan tembaga murni (native copper)

2. Pencetakan dan peleburan tembaga

3. Penemuan carnpuran perunggu.

Setiap tahap tersebut, dari monometallic ke polymetallic memerlukan ketrampilan khusus manusia.

Dalam tahap pertama, manusia menemukan tembaga masih dalam bentuk yang murni di permukaan tanah (belum melalui cara penambangan). Pengerjaannya sangat sederhana sekali, yaitu hanya ditempa berulang-ulang sampai mendapatkan bentuk alat yang diinginkan seperti kalau mereka membuat alat-alat batu. Dengan kata lain, pengerjaan 'native copper' masih merupakan kelanjutan teknologi batu. Logam tersebut tidak begitu keras. Percobaan-percobaan yang dilakukan membuktikan bahwa tembaga jenis ini dapat ditempa sedemikian rupa tanpa retak-retak.

Tahap kedua, setelah melalui pengalaman-pengalaman yang lama, logam tersebut mulai dicairkan untuk dicetak. Kemudian mereka mengenal cara-cara melebur tembaga dari bijihnya. Tingkat ini memerlukan pengetahuan dan ketrampilan yang lebih rumit, antara lain adalah menyediakan bahan baku dan tempat pembakaran yang dapat menghasilkan temperatur tinggi karena titik lebur tembaga adalah $1083^{\circ} \mathrm{C}$. Bukti arkeologis tentang situs peleburan logam, dan penambangan logam telah ditemukan di Timna, Israel. Penentuan umur situs tersebut berkisar pada tahun ribuan ke IV sebelum Masehi (Rothenberg, 1972). 
Tahap ketiga selanjutnya merupakan tahap yang sangat penting di dalam metalurgi prasejarah. Pada tahap ini ditemukan cara pencampuran tembaga dengan logam lain untuk menghasilkan perunggu. Cara-cara untuk mendapatkan campuran perunggu ini tidak diketahui dengan pasti. $\mathrm{Ke}$ mungkinan-kemungkinannya ialah:

1. melebur bersama tembaga dan timah

2. dengan memasukkan mineral yang mengandung timah (cassiterite) ke dalam tembaga yang sudah mencair

3. dengan melebur mineral yang secara alamiah mengandung unsur-unsur tembaga dan timah (Stannite).

Jelaslah bahwa perkembangan arkeometalurgi dari tingkat sederhana (tembaga murni) sampai ke tingkat perunggu merupakan masa eksperimen yang sangat panjang dari tahun ribuan ke 7 S.M. sampai tahun ribuan ke-3 S.M.

\section{Metalografi}

Telah disebut di muka bahwa jangkauan studi metalurgi ialah mengetahui teknik pembuatan alat-alat logam. Studi khusus untuk tujuan tersebut ialah analisis metalografi. Studi ini bertujuan untuk mendapatkan gambaran yang lebih lengkap tentang komposisi unsur-unsurnya maupun bentukbentuk mikrostrukturnya.

Dasar dari metalografi ini terletak pada kenyataan bahwa metal bersifat kristal, terjadi dari himpunan kristal yang masing-masing kristal disebut 'grain'. Metal terdiri atas susunan atom-atom yang membentuk pola geometris dalam tiga dimensi, ada yang menyerupai bentuk kubus atau segi enam, tergantung pada jenis metal itu sendiri.

Jika metal dipanaskan sampai mencair maka susunan atom-atomnya akan berubah menjadi tidak teratur tergantung oleh cepat dan lambatnya proses pendinginan. Apabila pendinginan terjadi secara lambat maka butiranbutiran kristal tampak lebih besar dari pada yang mengalami pendinginan secara cepat. Di dalam proses pemadatan (dari cair menjadi padat), kristalkristal akan membentuk pola seperti bentuk 'pohon cumara' (dendrite).

Struktur yang berpola 'dendrite' terlihat pada benda logam (perunggu) yang teknik pembuatannya hanya dicetak. Sedangkan pada benda-benda logam yang ditempa, pola 'dendrite' tersebut menjadi rusak tidak beraturan. Butiran kristal yang tadinya beraturan (equioxial) menjadi memanjang. Di dalam garis-garis batas butiran kristal terdapat garis-garis sejajar. Dengan melihat pola-pola struktur metalografi kita akan dapat menentukan teknik pembuatan benda-benda logam.

\section{Teknologi Benda-benda Logam}

Analisis terhadap alat-alat logam mempunyai bermacam-macam tujuan. 
Pada umumnya studi benda-benda logam lebih memusatkan perhatian pada analisis teknis yang akan berguna untuk merekonstruksi teknologi masa lampau.

Secara garis besar, teknik pembuatan alat-alat dari logam dapat dibedakan menjadi:

a. dicetak

b. ditempa.

\section{Teknik Cetak}

Pada umumnya benda-benda perunggu dibuat dengan teknik cetak. Namun tidak menutup kemungkinan bahwa benda-benda yang terbuat dari besi ada kalanya - meskipun sangat jarang dijumpai - dibuat dengan cara cetak. Pembuatan benda-benda logam dari besi dengan teknik cetak hanya ditemukan di Cina. Di Asia Tenggara dan Asia Barat, cara ini tidak ditemukan.

Terdapat dua metode pencetakan:

\section{a. Metode cetak langsung}

Dalam cara ini cairan logam dituang langsung ke dalam cetakan negatif. Setelah dingin cetakan dilepas, maka diperoleh artefak yang diinginkan. Cetakan negatif terbuat dari batu, logam, atau tanah liat. Menurut macamnya, cetakan benda-benda logam dapat dibedakan menjadi:

1. cetakan tunggal (single mould)

2. cetakan setangkup (bivalve mould)

3. cetakan ganda (multi mould atau piece mould)

Cetakan tunggal disebut juga cetakan terbuka (open mould) iaiah alat pencetak benda logam yang sederhana. Biasanya dibuat dari batu yang dilubangi menurut bentuk artefak yang diinginkan. Oleh karena itu akan menghasil artefak yang salah satu sisinya datar. Hal ini terjadi karena cetakannya tidak berpasangan, dan sebelum logam cair dituang, di atas permukaan .cetakan diberi tutup, seperti terlihat pada gambar berikut.

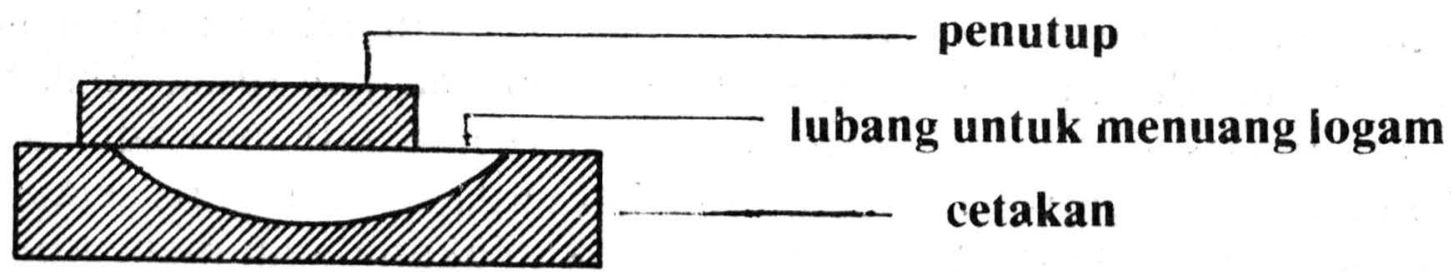

Berbeda dengan cetakan tunggal, maka tipe cetakan setakub akan menghasilkan artefak yang simetris pada ke dua sisinya. Cetakan tipe ini terdiri atas dua bagian, masing-masing mewakıli separuh dari bentuk 
artefak sesungguhnya. Biasanya dipakai untuk membuat kapak, ujung tombak, atau nekara, dan sebagainya. Apabila artefaknya berongga, maka sebelum logam dituang, ke dalam cetakan negatif dimasukkan pengisi (core) dengan demikian akan terbentuk 'socket'. Teknik 'socket' ditemukan di Asia Tenggara seperti terbukti pada kapak perunggu, ujung tombak yang ditemukan di Thailand.

Cetakan tipe 'piece mould' terdiri atas bagian-bagian kecil cetakan yang kemudian disambung-sambung sehingga menjadi satu kesatuan. Benda-benda yang dicetak umumnya bejana, wadah makanan-minuman. Teknik cetak dengan cetakan ganda tersebut sangat populer di. Cina sejak jaman Prasejarah. Di luar Cina cara ini tidak dijumpai (Bardnard \& Sato, 1975).

\section{b. Metode cire perdue atau 'lost-wax'}

Metode cire perdue dipakai untuk benda-benda yang bervariasi bentuk, dekorasi, atau arca dan benda-benda yang tidak simetris. Proses pembuatannya meliputi tiga tahap, yaitu: positif, negatif, dan positif. Pertama-tama model benda yang diinginkan dibuat dari bahan lilin (positif). Kemudian model dibungkus selapis demi selapis dengan tanah liat dengan diberi lubang di beberapa tempat. Setelah kering, tanah liat beserta model lilin di dalamnya dibakar, lilin melelh ke luar nielalui lubang dan terbentuklah cetakan (negatif). Cairan logam kemudian dituang ke dalam cetakan. Untuk mengeluarkan benda logam yang sudah jadi, cetakan dari tanah tersebut dipecah.

Keuntungan menggunakan metode ini ialah dapat menghasilkan benda-benda perunggu yang tidak simetris, dengan hiasan yang beraneka ragam. Kerugiannya ialah bahwa cetakan negatifnya hanya sekali pakai.

\section{Teknik Tempa}

Alat-alat perunggu yang dicetak kadang-kadang dilanjutkan dengan penempaan pada bagian-bagian tertentu. Artefak-artefak biasanya berupa kapak, pisau, ujung tombak dan mata kail. Penempaan tersebut bertujuan untuk menambah keras dan kuat sehingga alat yang dimaksud tidak mudah retak atau pecah dalam penggunaan.

Penempaan yang berulang-ulang akan menyebabkan perunggu menjadi retak-retak dan rapuh. Apabila penempaan masih diperlukan, obyek harus dipanaskan supaya menjadi lebih lunak. Proses menempa, kemudian memanaskan secara berturut-turut, dalam istilah metalurgi disebut "annealing". Pengerjaan seperti ini akan mengubah struktur metalografi yang dapat dibaca dari irisan artefaknya. Oleh karena itu analisis metalografis penting sekali untuk dapat mengetahui teknologi pembuatan benda logam. 


\section{Logam Campuran: Perunggu, Kuningan}

Perunggu adalah campuran tembaga $(\mathrm{Cu})$ sebagai logam dasar dengan unsur-unsur yang lain seperti timah (tin $=\mathrm{Sn}$ ), arsenic (As), timah hitam (lead $=\mathrm{Pb}$ ). Adapun yang disebut kuningan (brass), yang dikenal sesudah munculnya perunggu, ialah campuran tembaga $(\mathrm{Cu})$ dan zeng $(\mathrm{Zn})$.

Menurut jumlah unsur-unsur pokok pada logam campuran (alloy), dikenal ada dua macam:

a. 'binary alloys' - campuran yang terdiri atas dua unsur, seperti $\mathrm{Cu}+\mathrm{Sn}$. b. 'ternary alloys' - campuran tiga unsur, seperti $\mathrm{Cu}+\mathrm{Sn}+\mathrm{Pb}$.

Pada mulanya, pencampuran dua mineral yang berbeda tersebut ditemukan manusia untuk keinginan mendapatkan perubahan warna logam. Kemudian setelah melalui pengalaman yang panjang bertahun-tahun diketahui bahwa percampuran mineral-mineral tersebut membuat benda lebih kuat, lebih keras dan menaikkan tingkat fluiditas (mudah mengalir). Logam yang makin caur akan lebih mudah dceiak incinjadi benuk artefak yang beraneka ragam sesuai dengan ydng dungmkan manusia, Wheeler and Maddin, 1980: 106). Keuntungan yang lain lalan dengan menambahkan limah isn, ke dalam tembaga, akan menurunkan lılik icbur.

Akan tetapi penambahan timah ke dalam tembaga untuk mendapatkan artefak yang lebih kuat hanyalah sampai pada batas prosentase tertentu. Untuk perunggu, perbandingan tembaga: timah berkisar antara $90 \% \mathrm{Cu}+$ $10 \% \mathrm{Sn}$. Penambahan proporsi timah (Sn) makin banyak menyebabkan metal makin berwarna putih, disebut 'speculum metal', sampai maksimal $30 \%$. Prosentase Sn yang tinggi tersebut menyebabkan perunggu lebih getas, tidak bisa ditempa. Oleh karena itu biasanya benda perunggu yang kandungan timahnya tinggi ditemukan pada benda-benda perhiasan atau bendabenda penyerta upacara; tidak dijumpai pada benda-benda untuk kebutuhan tekris.

Timah hitam (lead) kadang-kadang ditambahkan pada campuran perunggu sampai sekitar $10 \%$. Penambahan iead menyebabkan logam campuran lebih cair dan mudah mengalir sehingga membantu sekali dalam menghasilkan benda-benda perunggu berkwalitas tinggi misalnya: nekara dan bejana, yang memerlukan dinding tipis (Haryono 1982).

Di Asia Tenggara dan di Cina, penambahan timah hitam pada campuran perunggu $(\mathrm{Cu}+\mathrm{Sn}$ ) nampaknya sudah dikenal sejak kurang lebih 2000 B.C. Di situs Non Nok Tha (Thailand) beberapa artefak perunggu yang telain dianalisis mempunyai kandungan lead. Menurut R. Pittioni (1971: 160) terdapatnya unsur lead tersebut karena memang ditambahkan secara sengaja. Juga beberapa artefak perunggu dari situs Ban Chiang mengandung lead sekitar 1-5,5\%. Di Cina sejak jaman dinasti Shang (abad 16 S.M.), beberapa bejana perunggu dan bahkan beberapa senjata perunggu mempunyai kan- 
dungan lead yang linggl. Para ahli menduga bahwa penambahan lead yang umum baik di Asia Tenggara maupun di Cina tersebut disebabkan oleh makin sedikitnya mineral tin di kawasan tersebut sehingga mineral tersebut menjadi bardng yang langkd dan mahal. Akan telapı rupanya penambahan lead iersebut kareila pertimbangan-pertumbangan teknis.

Dari uraian di muka tampak jelas bahwa masyarakat pada jaman logam sudah cukup tinggi pengetahuan dan ketrampilan mereka tentang seluk beluk logam, antara lain mengenai cara penambangan, cara membuat campuran, sifat-sifat kimia dari logam tersebut. Hal ini tentu saja karena cukup tersedia sumber-sumber yang mengandung bijih logam di Asia Tenggara. Menurut penelitian yang sudah dilakukan di wilayah Asia Tenggara, daerahdaerah Thailand bagian utara terus meluas ke selatan sampai Malaya banyak mengandung sumber-sumber tembaga, timah, antimoni, seng (United $\mathrm{Na}$. tion: 26 ).

Jenis mineral yang mempunyai kandungan timah (Sn) di Asia Tenggara antara lain: cassiterite $\left(\mathrm{SnO}_{2}\right)$, stannite $\left(\mathrm{Cu}_{2} \mathrm{~S}(\mathrm{Fe}, \mathrm{Zn}) \mathrm{S}\right.$. Sn $\left.\mathrm{S}_{2}\right)$, dan malayaite $\left(\mathrm{CaO} . \mathrm{SnO}_{2} . \mathrm{SiO}_{2}\right)$ (Hosking, 1970). Adapun jenis-jenis mineral yang mengandung tembaga $(\mathrm{Cu})$ termasuk: chalcocite $\left(\mathrm{Cu}_{2} \mathrm{~S}\right)$, malachite $\left(\mathrm{Cu}_{2}\right.$ $\left.(\mathrm{OH})_{2} \mathrm{Co}_{3}\right)$, chalcopyrites $\left(\mathrm{Cu}_{2} \mathrm{Fe}_{2} \mathrm{~S}_{4}\right)$, cuprite $\left(\mathrm{Cu}_{2} \mathrm{O}\right)$, Azurite $\left(\mathrm{Cu}_{3}(\mathrm{OH})_{2}\right.$ $\left.\left(\mathrm{CO}_{3}\right)_{2}\right)$, dan beberapa jenis lainnya. (Hoskin:. 1970).

\section{Metalurgi dan Arkeologi}

Bahwa penelitian arkeologi sekarang ini melibatkan suatu kerja sama dengan disiplin lain sudah jelas. Dalam interpretasi, data arkeologi pun memerlukan hasil-hasil analisis yang dikerjakan oleh ahli-ahli lain. Kalau sekarang ahli arkeologi juga mempelajari metalurgi bukan berarti kita ingin menjadi ahli metalurgi, akan tetapi paling tidak kita mengetahui dasardasar metalurgi yang diperlukan oleh artkeologi.

Arkeologi tidak lagi hanya memandang artefak-artefak logam dari titik pandang keindahan artefaknya, hiasan-hiasananriya, akan tetapi lebih dari itu diamati pula bagaimana orang membuat artefak tersebut, di mana mereka membuatnya, dari mana inereka mendapat bahan-bahan logam, dan masih banyak pertanyaan lainnya. Tentu saja tidak semua pertanyaan dapat dijawab, tergantung dari bukti-bukti arkeologis yang ada. Banyak data yang harus diperhatikan dalam ekskavasi selain benda logam yang sudah jadi, seperti misalnya wadah pelebur logam, cetakan negatif, kerak-kerak logam atau gumpalan logam.

Kita mempunyai banyak peninggalan berupa benda perunggu, tembaga, besi, baik dari masa prasejarah maupun masa klasik. Masih banyak analisis yang perlu dilakukan terhadap peninggalan tersebut. Suatu contoh dapat dikemukakan misalnya: prasasti logam, arca perunggu. Analisis 
komposisi unsur-unsurnya mungkin akan memberikan informasi yang banyak. Apakah komposisi unsur arca perunggu dari suatu masa berbeda dengan arca perunggu dari masa lain, akan dapat diketahui dari perbandingan komposisi unsurnya. Perbandingan komposisi unsur mungkin juga akan berguna untuk mengetahui, apakah suatu arca perunggu itu tiruan (sekarang).

Dalam interpretasi arkeologi khususnya tentang metalurgi, banyak data etnografis yang dapat dipakai. Di beberapa tempat masih ada pembuatan benda-benda dengan teknik sederhana (tradisional). Dapat kiranya dari data etnografis diproyeksikan ke masa lampau. Relief dari candi Sukuh teritang pande logam membuktikan bahwa teknik sederhana sekarang ini merupakan kelanjutan dari periode candi Sukuh. Dari masa candi Sukuh ke belakang masih menunggu bukti-bukti arkeologis lebih lanjui.Sumbersumber prasasti jelas menyebutkan para pande logam antara lain adalah pande perunggu (pande gangsa), pande besi (pande wsi), pande tembaga (pande tamwaga).

Situs-situs arkeologi yang berhubungan dengan kegiaian pembuatan benda-benda logam akhir-akhir ini mulai muncul seperti di Banten, (Mundardjito 1977). Bukti-bukti arkeologis yang kita harapkan antara lain adalah: cetakan negatif, wadah pelebur logam (kowi), sisa-sisa ububan, bekasbekas lubang pembakaran.

Situs penambangan logam mungkin sukar ditemukan sebab tempattempat penambangan logam mungkin sudah rusak oleh penambangan sekarang. Situs penambangan kuna yang pernah ditemukan terletak di Cina di situs Tonglushan, dari sekitar tahun ribuan kedua sebelum Masehi.

Sebagai penutup lukisan singkat ini, dapat dinyatakan bahwa studi arkeometalurgi mempunyai hubungan erat dengan arkeologi, seperti halnya antara arkeologi dengan disiplin yang lain. Dalam pengembangannya perlu mendapat perhatian kita semua.

* Makalah ini pernah dibacakan dalam ceramah Hımpunan Mahasıswa Arkeologe lakulıas Sastra UGM pada tanggal 11 Pebruari 1983 


\section{Keouctakaan:}

Barnard, Noel \& Sato Tamotsa

1975 Metallurgi eal Remains of Ancient China Tokyo, Nichiosha Binford, L.R.

1968 Archacological perspectives. S.R. Binford and L.R. Binford (eds) New Perspectives in Archaeology, halm. 5 - 32. Chicago: Aldine

Gifford, D.P

1981 Taphonomy and Palaeocology: A Critical review of Archaeology's Sister Disciplines.

M.B. Schffer (ed) Advances in Archaeological Method and Theory. New York: Academic Press

Grosvenor, A.W (ed)

1954 Basic Metallurgy Vol I. Ohio: American Seciety for Metals. Haryono, Timbul

1982 Ancient Bronze Technology in Northeast Thailand and North China: A Comparative Study. Master thesis. University of Pennsylvania (Unpubished)

Hodges, Henry

1982 Artifacts. An introduction to early materials and technology, New Jersey: Humanntes Pres

London: John Baker.

Hosking, K.F.G.

1970 The Primary Tin Deposits of South-East Asia.

Mineral Science Engineering: 24-50.

Martin, Paul S

1971 The Revolution in Anthropology. American Antiquity 36 (2) 1-8.

Mundardjito

1977 Wadah pelebur logam dari ekskavasi Banten 1976 sumbangan data bagi sejarah teknologi.

MISI jilid VII (2): 57-88.

Pittioni, R

1971 Spectro-analytical Research on Bronze from Northeastern Thailand. Translated by Karl Hutterer, Asian Perspectives XIII: $158-162$.

Rothenberg. Beno

1972 Timna: Valley of the Biblical Copper Mines London: Thames and Hudson.

Schiffer, M.B.

1976 Behavioral Archaeology. New York: Academic Press. 
United Nations

t.th Mineral Resources of the Lower Mekong Basin and Adjacent Areas of Khmer Republic, Laos, Thailand and Republikc of Biet-Nam. Mineral Resources Davelopment Series No. 39.

Wheeler, Tamara Stech and Robert Maddin

1976 The Techniques of the Early Thai Metalsmith. Expedition 18 (2): 38-47.

1980 Metallurgy and Ancient Man. Th. A. Whertime and. J.D. Muhly (eds). The Coming of the Age of Iron. New Haven and London: Yale University Perss. halm. 99-126. 


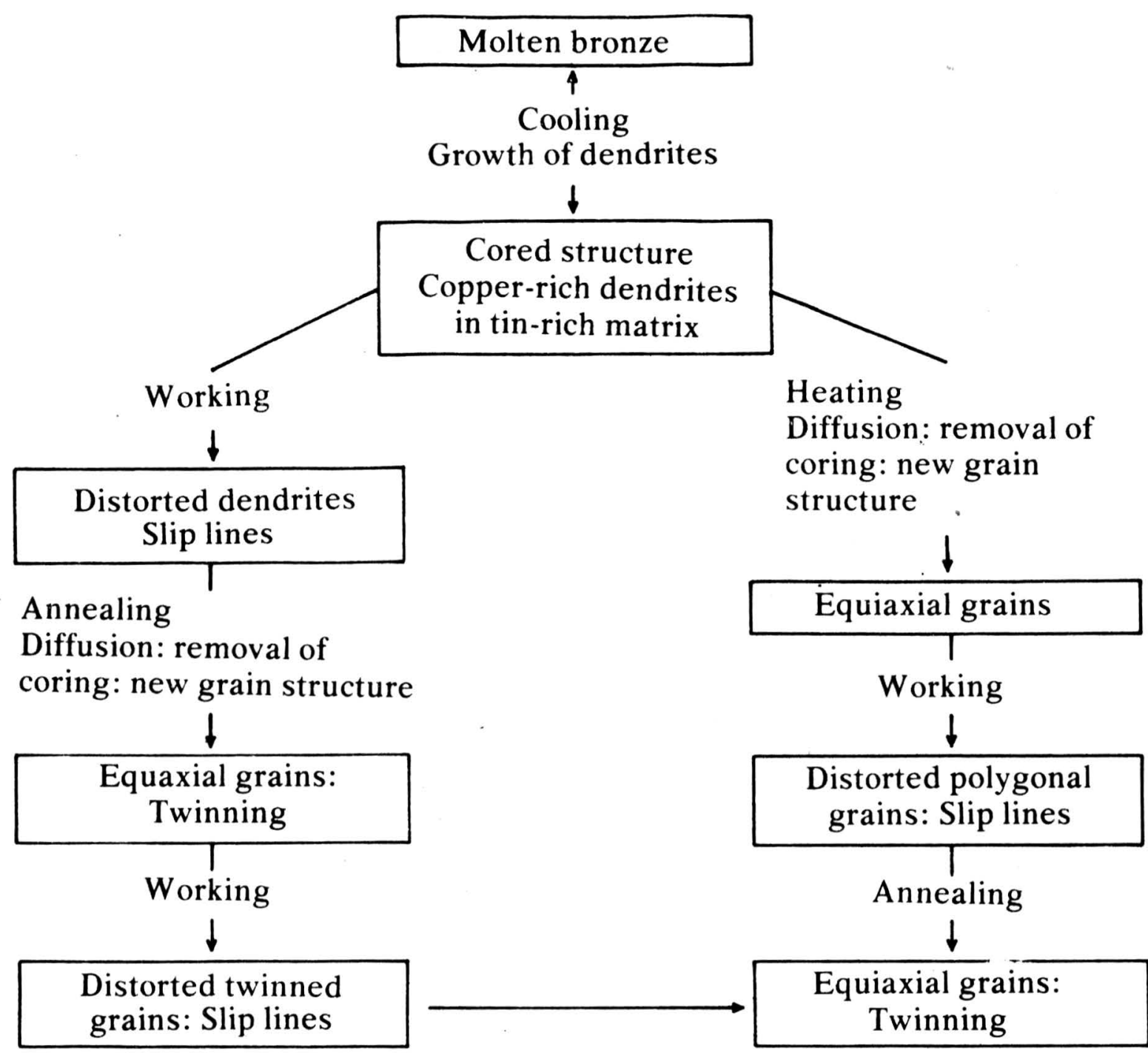

Diagram metalografi perunggu (dikutip dari Hodges 1976: 215).
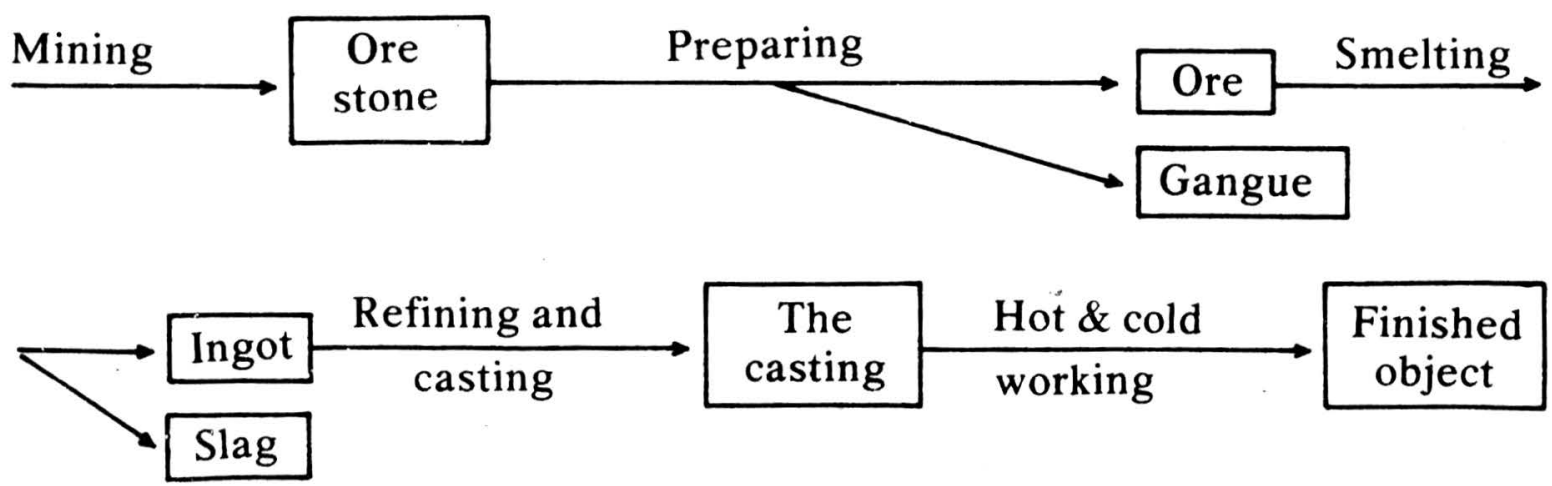

Proses pengadaan bijih tembaga untuk memproduksi artefak (dikutip dari Hodges 1976: 64). 